ECCOMAS

Proceedia
M. Papadrakakis, M. Fragiadakis (eds.)

Rhodes Island, Greece, 15-17 June 2017

\title{
ANALYSES OF THE SEISMIC ACTIONS RECORDED DURING THE 2016 CENTRAL ITALY SEISMIC SEQUENCE: OBSERVED VS CODE PROVISION VALUES
}

\author{
F.C. Ponzo ${ }^{1}$, R. Ditommaso ${ }^{1}$, A. Nigro ${ }^{1}$, C. Iacovino $^{1}$ \\ ${ }^{1}$ School of Engineering, University of Basilicata, Italy \\ felice.ponzo@unibas.it \\ r.ditommaso@unibas.it \\ antonella.nigro@unibas.it \\ chiara.iacovino@unibas.it
}

Keywords: Central Italy Earthquake, Seismic Parameters, NTC 2008.

\begin{abstract}
On August 24, 2016 at 03.36 a.m. (Italian time), a Mw 6.0 earthquake struck an extensive portion of the Central Italy. The epicentre was located among the municipalities of Accumoli (province of Rieti), Amatrice (province of Rieti) and Arquata del Tronto (province of Ascoli Piceno). After this first seismic event, from the academic point of view, several technical and scientific activities started with the aim to carry out preliminary evaluations on the characteristics of the seismic sequence, in order to interpret the possible effects of soil amplification in the areas affected by the earthquake and the damages observed on structures. The activities are continuing after the Mw 5.9 earthquake on October 26, 2016 and the Mw 6.5 earthquake on October 30, 2016. The strong motion recorded signals have been analysed in terms of peaks (PGA, PGV and PGD) and integral seismic parameters starting from data recorded by the closest stations to the epicentres. Several comparisons between the elastic response spectra retrieved from accelerometric recordings and the elastic demand spectra provided by the Italian seismic code (NTC 2008) have also been performed.
\end{abstract}

(C) 2017 The Authors. Published by Eccomas Proceedia.

Peer-review under responsibility of the organizing committee of COMPDYN 2017.

doi: $10.7712 / 120117.5694 .18156$ 


\section{INTRODUCTION}

The earthquake occurred on October 30, 2016 at 06:40:17 UTC, (07:40:17, Italian time) was the Italian strongest event after the 1980 Irpinia earthquake $\left(\mathrm{M}_{\mathrm{W}} 6.9\right)$. The local magnitude evaluated by the INGV is equal to $6.1 \mathrm{M}_{\mathrm{L}}$ while the moment magnitude is equal to $6.5 \mathrm{M}_{\mathrm{W}}$. The earthquake affected the provinces of Perugia, Rieti and Macerata and was strongly felt in central Italy; the epicenter is located $5 \mathrm{~km}$ far from Norcia, $7 \mathrm{~km}$ far from Castelsantangelo sul Nera and Preci, $10 \mathrm{~km}$ far from Visso. Up to this moment the $30^{\text {th }}$ of October earthquake is the strongest event of the sequence which began with the earthquake of August $24\left(\mathrm{M}_{\mathrm{W}} 6.0\right)$, followed by a quake of magnitude $\mathrm{M}_{\mathrm{W}}$ equal to 5.9 of October 26, 2016 [1].

The main events of the ongoing Monti della Laga-Valnerina seismic sequence occurred in a territory that was affected by relevant earthquakes in the past. Some of these historical earthquakes occurred within sequences, none of which comparable with the current one.

In the Amatrice area, where the major effects of the August 24 earthquake took place, the most distinctive feature is a cluster of four earthquakes occurred in: 1627 (Accumoli, $\mathrm{M}_{\mathrm{W}}$ 5.3); 1639 (Amatrice, $\mathrm{M}_{\mathrm{W}}$ 6.2); 1646 (Monti della Laga, $\mathrm{M}_{\mathrm{W}}$ 5.9) and 1672 (Amatrice, $\mathrm{M}_{\mathrm{W}}$ 5.3). In Valnerina, the earthquakes located closest to the epicentre of the October 30 main event are those of 1328 (Valnerina, $\mathrm{M}_{\mathrm{W}}$ 6.5); 1719 (Valnerina, M 5.6); 1730 (Valnerina, $\mathrm{M}_{\mathrm{W}}$ 6) and 1859 (Valnerina, $M_{W}$ 5.7). In the Visso-Ussita-Castelsantangelo sul Nera area, the intensity degrees now being assessed for the October 26 events appear very likely to be the historical maximum for this sector, at the current state of knowledge [1].

The area struck by the earthquake sequence is characterised by active fault systems already described in the geological literature published since the 90 s of the past century. Particularly, the Apennine sector between Campotosto (south) and Colfiorito (north) presents normal fault systems trending NW-SE to NNW-SSE, with surface expression longer about $20-30 \mathrm{~km}$, made of minor fault sections about $5-10 \mathrm{~km}$ long. The fault systems and the related fault sections are supposed to represent the superficial expression of seismogenic sources potentially responsible for earthquakes with $\mathrm{M}$ ranging between 5.5 and 7.0 [1].

After the Mw 6.0 mainshock of August 24, 2016 several activities were started in order to perform some preliminary evaluations on the seismic parameters of the recent seismic sequence that affected central Italy and to evaluate possible effects of local soil amplification in the areas affected by the earthquake [2].

Ambient vibration acquisitions have been performed using two three-directional velocimetric synchronized stations, with a natural frequency equal to $0.5 \mathrm{~Hz}$ and a digitizer resolution of equal to $24 \mathrm{bit}$.

This paper shows preliminary results of the experimental campaign carried out on $13^{\text {th }}$ and $14^{\text {th }}$ of September 2016 in the town of Amatrice. The activities are continuing after the events of the seismic sequence of 26 October and 30 October, 2016. Particularly, starting from the accelerometric time-histories acquired the RAN (Italian Accelerometric Network), peak (PGA) and integral parameters (Housner Intensity) have been evaluated and compared with Italian Seismic Code provisions.

\section{PRELIMINARY ANALYSIS OF THE ONGOING SEISMIC SEQUENCE}

The preliminary results described in this section are related to the Mw 6.0 mainshock of August 24, 2016 acquired by the accelerometric AMT station and to the seismic sequence of October 26 and October 30, 2016 acquired by the accelerometric CNE and NRC stations, respectively. 
The three different earthquakes analysed in this work have been acquired using a sampling frequency equal to $200 \mathrm{~Hz}$ (data ITACA INGV).

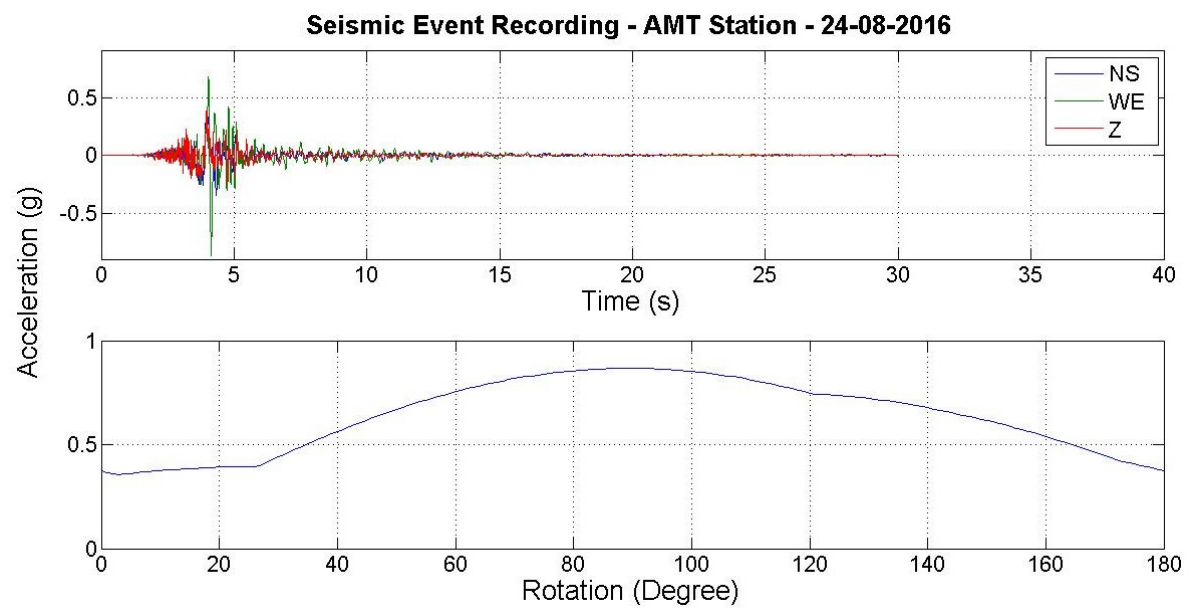

Figure 1: Earthquake on August 24, 2016 - accelerometric recordings and rotational analysis.

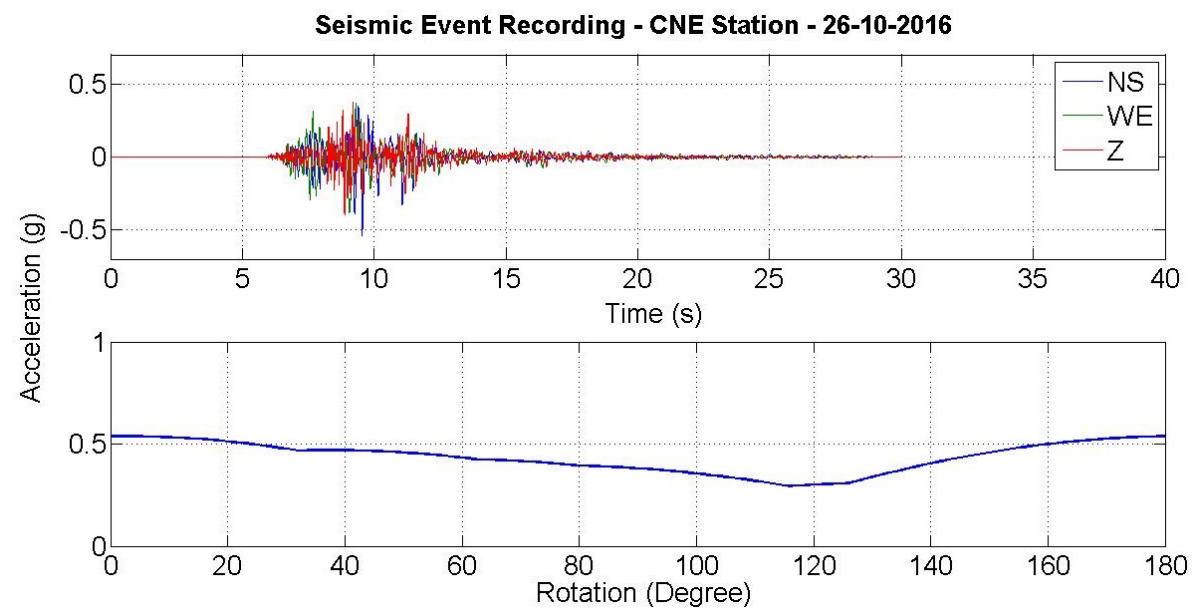

Figure 2: Earthquake on October 26, 2016 - accelerometric recordings and rotational analysis.

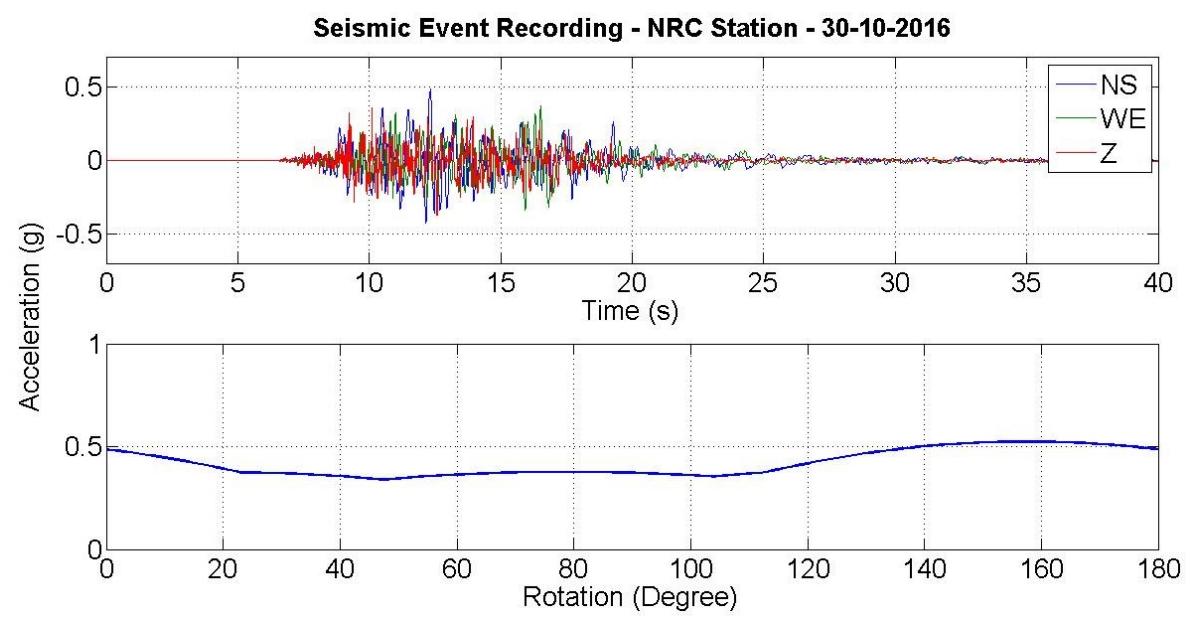

Figure 3: Earthquake on October 30, 2016 - accelerometric recordings and rotational analysis. 
The mainshock recorded by the AMT station is characterized by a Peak Ground Acceleration (PGA) value equal to $0.85 \mathrm{~g}$ (Figure 1). PGA values of the $26^{\text {th }}$ and $30^{\text {th }}$ of October seismic events are $0.53 \mathrm{~g}$ and $0.51 \mathrm{~g}$, respectively.

Figures 4, 5, 6 show the rotational acceleration response spectra related to the above mentioned seismic events.

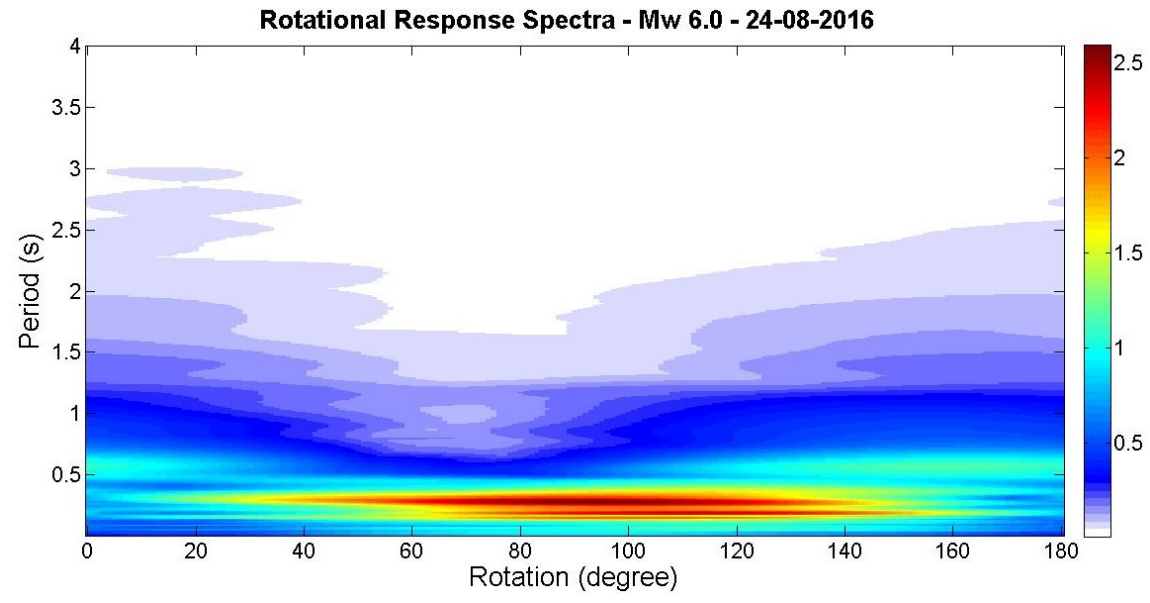

Figure 4: Rotational acceleration response spectra of the 24th of August 2016 seismic event.

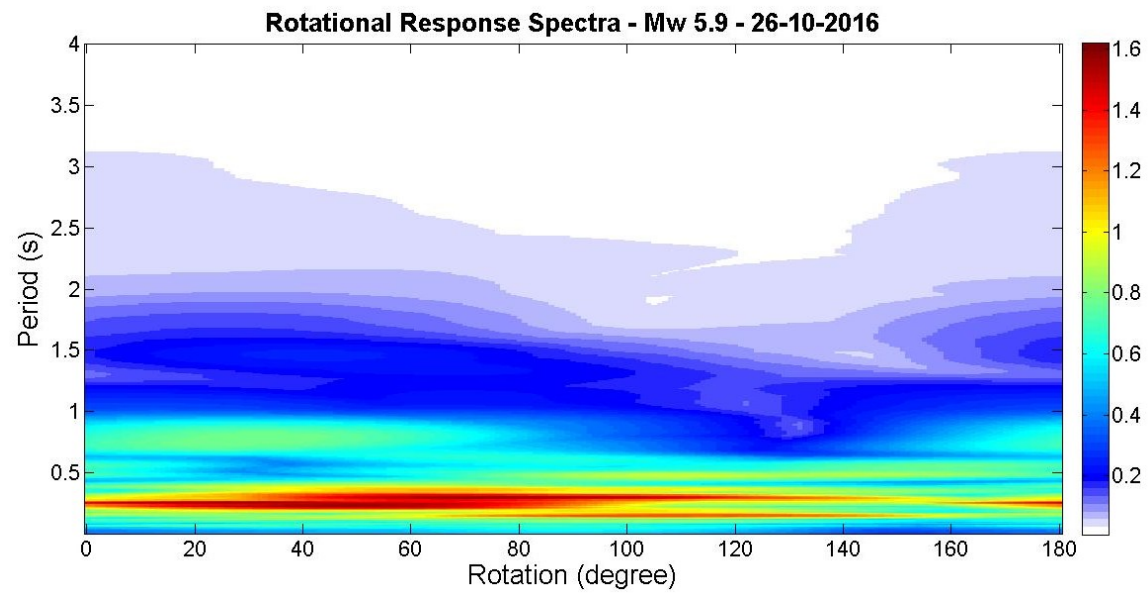

Figure 5: Rotational acceleration response spectra of the 26th of October 2016 seismic event.

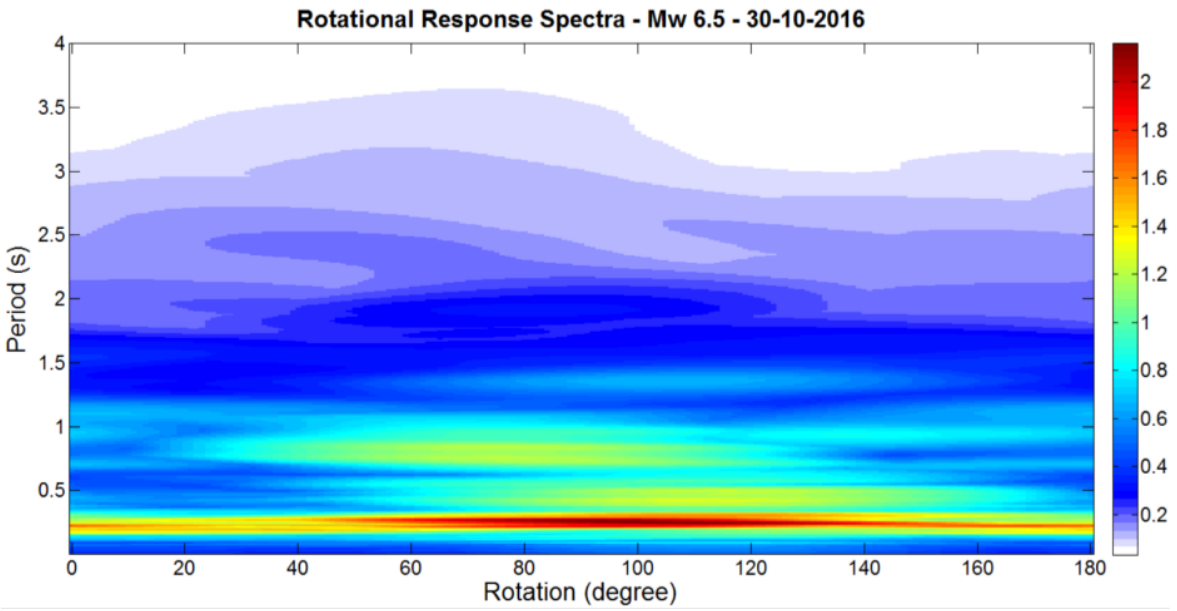

Figure 6: Rotational acceleration response spectra of the 30th of October 2016 seismic event. 
For the mainshock of August 24, 2016 it can be observed that the maximum acceleration has been recorded along the WE direction while the maximum acceleration is less than $0.5 \mathrm{~g}$ along the NS direction [2]. The preliminary analyses showed that the maximum spectral acceleration, equal to $2.586 \mathrm{~g}$, occurred along a direction at $90^{\circ}$ from the NS direction in correspondence of a period equal to $0.28 \mathrm{~s}$. For the $26^{\text {th }}$ of October seismic event, the maximum spectral acceleration, equal to $1.6 \mathrm{~g}$, occurred along a direction at $45^{\circ}$ from the NS direction in correspondence of a period equal to $0.26 \mathrm{~s}$, while, for the $30^{\text {th }}$ of October seismic event, the maximum spectral acceleration, equal to $2.16 \mathrm{~g}$, occurred along a direction at $89^{\circ}$ from the NS direction in correspondence of a period equal to $0.27 \mathrm{~s}$. Figures $7,8,9$ show the results of the time-frequency analysis of the three earthquakes.
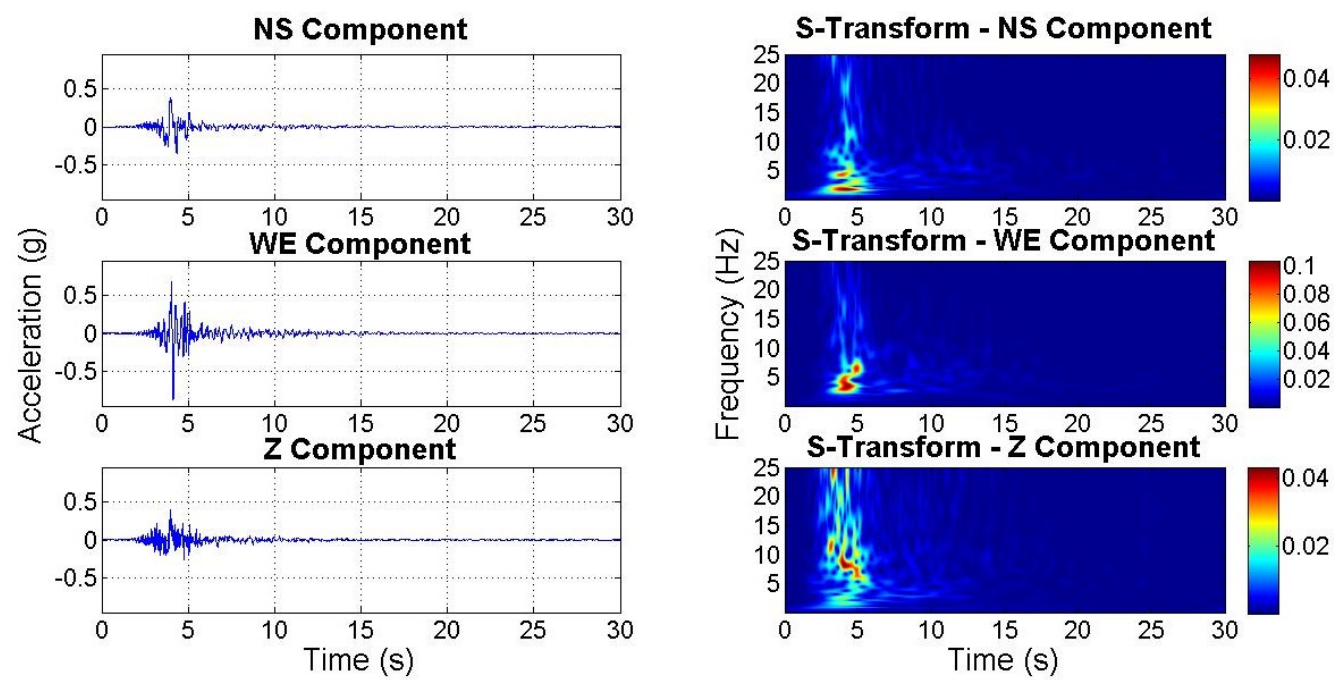

Figure 7: Stockwell Transform of the 24th of August 2016 seismic event.
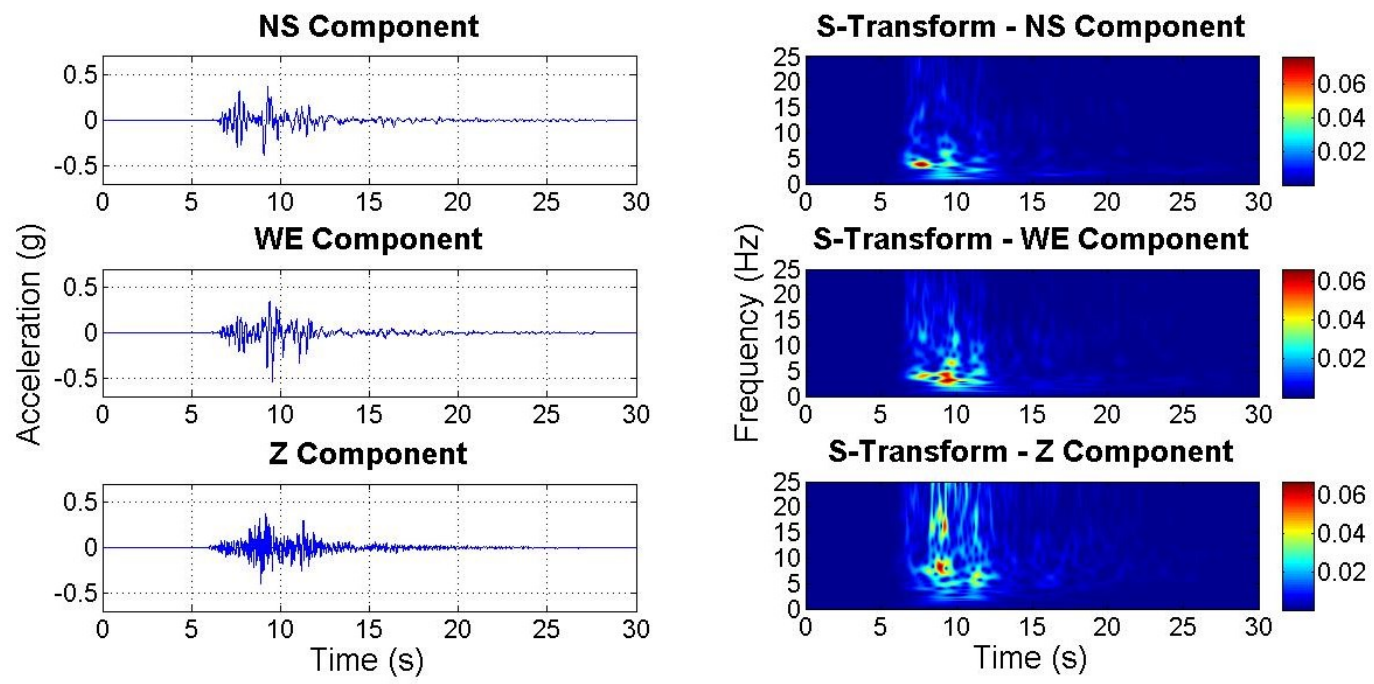

Figure 8: Stockwell Transform of the 26th of October 2016 seismic event. 

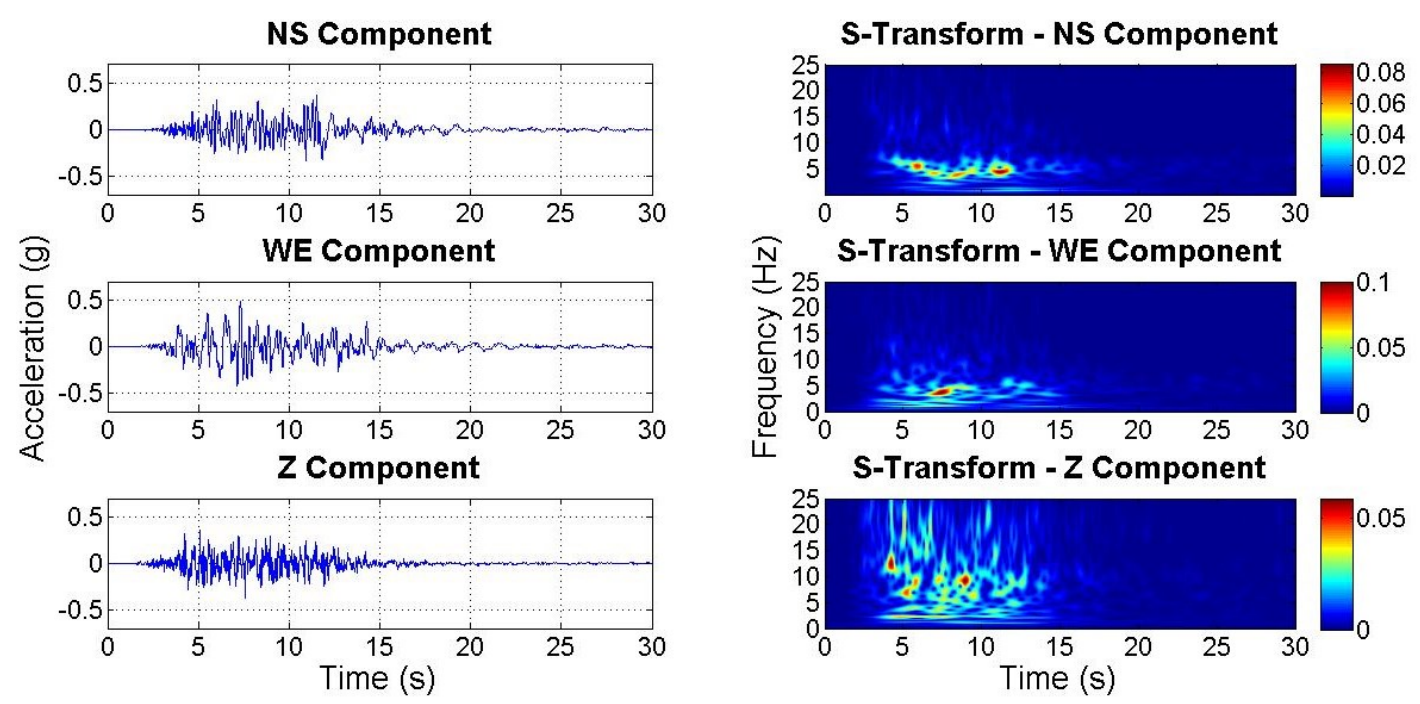

Figure 9: Stockwell Transform of the 30th of October 2016 seismic event (mainshock).

The analyses performed by the Stockwell Transform show an higher energy of the WE component for the mainshock August 24, 2016. Furthermore, the maximum energy was released in a range of frequencies close to $2 \mathrm{~Hz}$ (NS direction) and between $2 \mathrm{~Hz}$ and $6 \mathrm{~Hz}$ (WE direction). For the vertical component, a peak value can be observed in a range of frequencies between $7.5 \mathrm{~Hz}$ and $9 \mathrm{~Hz}$. For the $26^{\text {th }}$ of October event, the maximum energy was released in a range of frequencies close to $4 \mathrm{~Hz}$ (NS direction) and between $3 \mathrm{~Hz}$ and $5 \mathrm{~Hz}$ (WE direction). For the $30^{\text {th }}$ of October event, the maximum energy was released in a range of frequencies between $4 \mathrm{~Hz}$ and $5 \mathrm{~Hz}$ (NS direction) and between $3 \mathrm{~Hz}$ and $5 \mathrm{~Hz}$ (WE direction).

\section{AMBIENT VIBRATION MEASUREMENTS PERFORMED IN THE TOWN OF AMATRICE}

In order to characterize the dynamic behaviour of the soil in the most damaged area of Amatrice, several ambient vibration measurements have been performed on September 14, 2016 (Figure 10a). Figure 10 shows the preliminary results of the experimental campaign in terms of HVSR (Horizontal to Vertical Spectral Ratio) in three different locations [2].
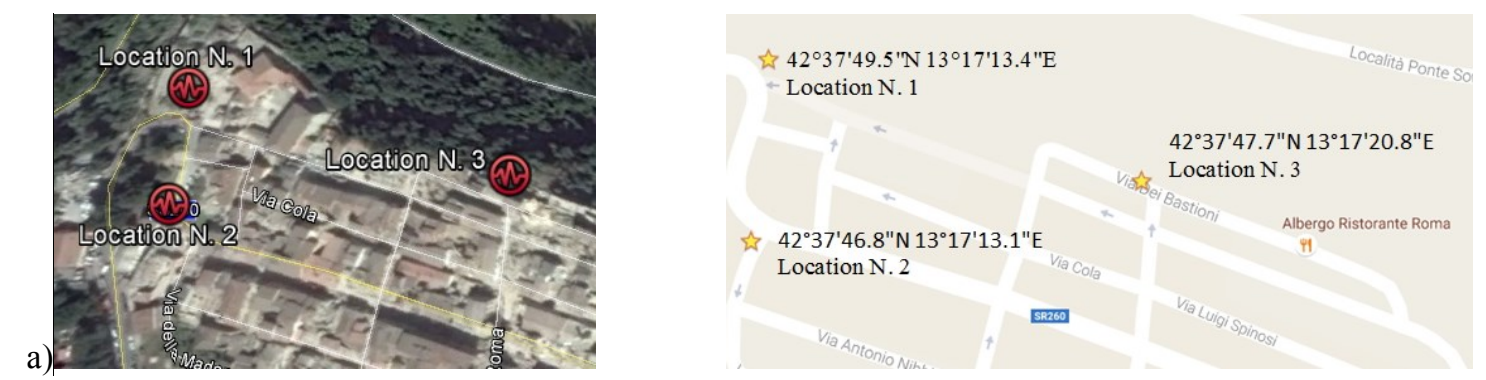

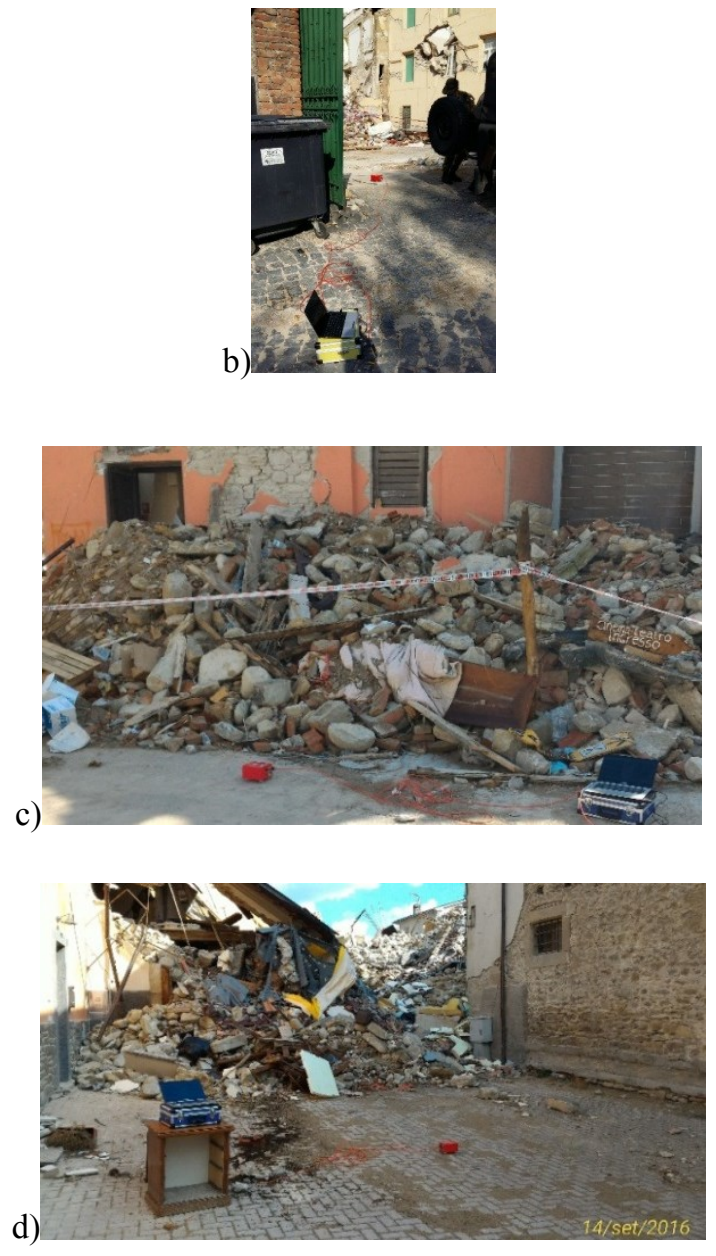
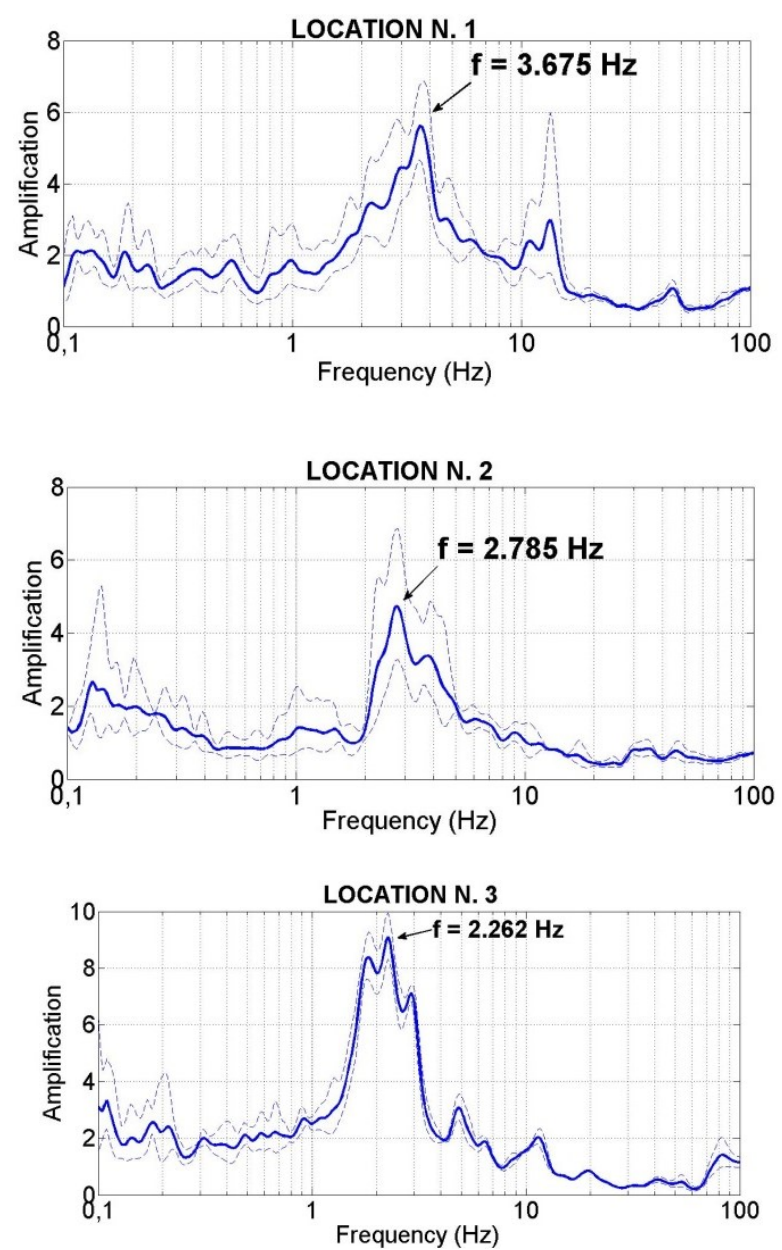

Figure 10: a) Map and GPS coordinates of the sites of ambient vibration measurements carried out in the town of Amatrice - b) Analysis HVSR - Location n. 1 ; c) Analysis HVSR - Location n. 2; d) Analysis HVSR Location n. 3.

Analysing preliminary results, the resonance frequencies are next to the frequency at which the earthquake has exhibited the maximum value of spectral acceleration (Period $=0.28 \mathrm{~s}=>$ Frequency $=3.57 \mathrm{~Hz}$ ) (Figure 4). Furthermore, it can be observed that the investigated sites exhibit a significant amplification peak that could affect structures characterised by a range of frequencies between 2 and $5 \mathrm{~Hz}$.

\section{ANALYSIS OF ACCELEROMETRIC RECORDED DATA}

Starting from the Mw 6.0 mainshock of August 24, 2016 some activities are continuing after the events of the seismic sequence of October 26 and October 30, 2016. Particularly, the strong motion recorded signals in terms of peak (PGA, PGV and PGD) and integral (Housner Intensity) seismic parameters have been analysed starting from data recorded by the closest stations to the epicentres [3].

The National Accelerometric Network (RAN) managed by the Italian Department of Civil Protection recorded a great deal of accelerometric data of the ongoing Monti della LagaValnerina seismic sequence. Three different stations have been selected: AMT - Amatrice for the $24^{\text {th }}$ of August main shock, CNE - Castelsantangelo sul Nera for the $26^{\text {th }}$ of October earthquake, NRC - Norcia for the $30^{\text {th }}$ of October earthquake. Table 1 shows the selected 
strong motion stations with their site coordinates, EC8 [4] soil type classification, epicentral $\left(\mathrm{R}_{\mathrm{EP}}\right)$ and Joyner-Boore distance $\left(\mathrm{R}_{\mathrm{JB}}\right)[5]$ and magnitude.

\begin{tabular}{|c|c|c|c|c|c|c|c|c|c|}
\hline $\begin{array}{c}\text { Date } \\
(Y Y Y Y-M M- \\
\text { DD })\end{array}$ & $\begin{array}{c}\text { Station } \\
\text { Code }\end{array}$ & Name RAN Station & Latitude & Longitude & $\begin{array}{c}\text { EC8 Soil } \\
\text { Type }\end{array}$ & $\begin{array}{c}\mathrm{R}_{\mathrm{EP}} \\
(\mathrm{km})\end{array}$ & $\begin{array}{c}\mathrm{R}_{\mathrm{IB}} \\
(\mathrm{km})\end{array}$ & $\mathrm{M}_{\mathrm{W}}$ & $\mathrm{M}_{\mathrm{L}}$ \\
\hline $2016-08-24$ & AMT & AMATRICE & 42.6325 & 13.2862 & $\mathrm{~B}^{*}$ & 8.5 & - & 6.0 & 6.0 \\
\hline $2016-10-26$ & CNE & $\begin{array}{c}\text { CASTELSANTANGELO } \\
\text { SUL NERA }\end{array}$ & 42.8944 & 13.1528 & $\mathrm{C}^{*}$ & 2.5 & 0 & 5.9 & 5.9 \\
\hline $2016-10-30$ & NRC & NORCIA & 42.7925 & 13.0965 & B & 5.4 & 2.17 & 6.5 & 6.1 \\
\hline
\end{tabular}

Table 1: Near-field accelerometric stations with site coordinates, EC8 soil type classification, epicentral distance (REP), fault distance (RJB) and magnitude.

* indicates that site classification is not based on a direct Vs 30 measurement

\subsection{Peak parameters: PGA, PGV and PGD}

Peak Ground Acceleration (PGA), Velocity (PGV) and Displacement (PGD) values for the three components (horizontal: NS and WE; vertical: UP) at each station are reported in Table 2. With regard to the values of the PGA horizontal components, the maximum value ( 850 $\mathrm{cm} / \mathrm{s}^{2}$ ) was recorded for the WE component at the AMT station. High values have also been recorded at the other stations, particularly $527 \mathrm{~cm} / \mathrm{s}^{2}$ for CNE and $476 \mathrm{~cm} / \mathrm{s}^{2}$ for NRC. Also for the vertical component, high values of PGA have been observed, respectively 391, 389, $376 \mathrm{~cm} / \mathrm{s}^{2}$ for AMT, CNE and NRC.

In terms of PGV values on the horizontal plane, NRC and AMT stations show the maximum values (48.29 and $43.55 \mathrm{~cm} / \mathrm{s}$, WE direction), while smaller but still remarkable value has been found at the station CNE, equal to $23.08 \mathrm{~cm} / \mathrm{s}$. As for the PGV values, the maximum value of PGD $(17.98 \mathrm{~cm}$, WE direction) has been recorded by the NRC station. Lower values of PGD have been found at the other stations.

\begin{tabular}{|c|c|c|c|c|c|}
\hline $\begin{array}{c}\text { Date } \\
(\text { YYYY-MM-DD) }\end{array}$ & Station Code & Direction & $\begin{array}{c}\text { PGA_RAN } \\
\left(\mathrm{cm} / \mathrm{s}^{2}\right)\end{array}$ & $\begin{array}{c}\text { PGV_RAN } \\
(\mathrm{cm} / \mathrm{s})\end{array}$ & $\begin{array}{c}\text { PGD_RAN } \\
(\mathrm{cm})\end{array}$ \\
\hline \multirow{3}{*}{$2016-08-24$} & \multirow{3}{*}{ AMT } & WE & -850.804 & 43.549 & -3.265 \\
& & NS & 368.387 & -41.501 & 8.544 \\
& & UD & 391.368 & -33.695 & -8.871 \\
\hline \multirow{3}{*}{$2016-10-26$} & \multirow{2}{*}{ CNE } & WE & -527.006 & 23.076 & 2.728 \\
& & NS & -373.134 & -36.542 & 5.274 \\
& & UD & -389.218 & -19.579 & -3.008 \\
\hline \multirow{2}{*}{$2016-10-30$} & \multirow{2}{*}{ NRC } & WE & 476.428 & -48.293 & -17.978 \\
& & NS & 365.051 & 41.446 & 8.138 \\
& & UD & -376.529 & 25.597 & 6.414 \\
\hline
\end{tabular}

Table 2: Peak ground acceleration (PGA), Velocity (PGV) and Displacement (PGD) values at the recording stations (AMT, CNE and NRC) for horizontal (NS and WE) and vertical (UP) components.

\subsection{Housner Intensity}

As an alternative to PGA or other seismic peak parameters, some studies [6,7] have demonstrated that Housner Intensity [8] can be an effective parameter to correlate the severity of seismic motions to structural damage, particularly, in cases of existing non-ductile Reinforced Concrete (RC) buildings [9]. The $\mathrm{I}_{\mathrm{H}}$ values for the recorded data three different 
main shocks have been computed. $\mathrm{I}_{\mathrm{H}}$ is calculated as the area under the pseudo-velocity response spectrum $(S \mathrm{v})$, as shown in Eq. (1):

$$
I_{H}=\int_{T_{\text {inf }}}^{T_{\text {sup }}} S_{v}(T, \xi) d T
$$

where $\mathrm{T}$ is the fundamental period of the structure under examination, $\xi$ is the damping ratio (equal to $5 \%$ in the analyses developed in this work), $\mathrm{T}_{\text {inf }}$ and $\mathrm{T}_{\text {sup }}$ define the interval of period values where ordinary buildings can be mostly placed. In the present work the period range $[0.2-2 \mathrm{~s}]$ has been used, in accordance with the choice adopted in the studies carried out for the previous seismic classification of the Italian territory proposed by the GNDT Working Group [10].

\begin{tabular}{|c|c|c|c|c|c|c|}
\hline $\begin{array}{c}\text { Date } \\
\text { (YYYY-MM-DD) }\end{array}$ & $\begin{array}{l}\text { Station } \\
\text { Code }\end{array}$ & Direction & $\begin{array}{c}\mathrm{I}_{\mathrm{H} \_\mathrm{NTC} 08} \\
\left(\mathrm{~T}_{\mathrm{R}}=475\right) \\
(\mathrm{m})\end{array}$ & $\begin{array}{c}\mathrm{I}_{\mathrm{H} \_\mathrm{NTC}} 08 \\
\left(\mathrm{~T}_{\mathrm{R}}=975\right) \\
(\mathrm{m})\end{array}$ & $\begin{array}{c}\mathrm{I}_{\mathrm{H} \_\mathrm{NTC} 08} \\
\left(\mathrm{~T}_{\mathrm{R}}=2475\right) \\
(\mathrm{m})\end{array}$ & $\begin{array}{c}\mathrm{I}_{\mathrm{H} \_\mathrm{RAN}} \\
(\mathrm{m})\end{array}$ \\
\hline \multirow{3}{*}{ 2016-08-24 } & \multirow{3}{*}{ AMT } & WE & 0.902 & 1.204 & 1.531 & 0.654 \\
\hline & & NS & 0.902 & 1.204 & 1.531 & 0.929 \\
\hline & & ROT & 0.902 & 1.204 & 1.531 & 0.654 \\
\hline \multirow{3}{*}{ 2016-10-26 } & \multirow{3}{*}{$\mathrm{CNE}$} & WE & 1.125 & 1.381 & 1.603 & 0.692 \\
\hline & & NS & 1.125 & 1.381 & 1.603 & 0.840 \\
\hline & & ROT & 1.125 & 1.381 & 1.603 & 0.692 \\
\hline \multirow{3}{*}{ 2016-10-30 } & \multirow{3}{*}{ NRC } & WE & 0.878 & 1.172 & 1.488 & 1.746 \\
\hline & & NS & 0.878 & 1.172 & 1.488 & 1.252 \\
\hline & & ROT & 0.878 & 1.172 & 1.488 & 1.651 \\
\hline
\end{tabular}

Table 3: Housner intensity for each recording station (AMT, CNE, NRC) for horizontal (NS and WE) and rotational (ROT) components and NTC08 Italian Code values for return periods (475, 975, 2475 years).

\section{COMPARISON BETWEEN RECORDED AND CODE PROVISION VALUES}

\subsection{Comparison in terms of PGA}

Table 4 shows Peak Ground Acceleration (PGA) values for the three components (horizontal: NS and WE and rotational: ROT) at each station and NTC08 Italian Code [11] PGA values for the three different return periods considered in this work. Furthermore, comparisons between code (NTC08) and recorded (RAN) PGA values has been performed in terms of differences according to Eq. (2):

$$
\Delta_{P G A, T_{R}}=\left(100 \cdot \frac{P G A_{N T C 08}-P G A_{R A N}}{P G A_{N T C 08}}\right)_{T_{R}}
$$

\begin{tabular}{|c|c|c|c|c|c|c|c|c|}
\hline $\begin{array}{c}\text { Station } \\
\text { Code }\end{array}$ & Direction & $\begin{array}{c}\text { PGA_ } \\
\text { NTC08 } \\
\left(\mathrm{T}_{\mathrm{R}}=475\right) \\
(\mathrm{g})\end{array}$ & $\begin{array}{c}\text { PGA_ } \\
\text { NTC08 } \\
\left(\mathrm{T}_{\mathrm{R}}=975\right) \\
(\mathrm{g})\end{array}$ & $\begin{array}{c}\text { PGA_ } \\
\text { NTC08 } \\
\left(\mathrm{T}_{\mathrm{R}}=2475\right) \\
(\mathrm{g})\end{array}$ & $\begin{array}{c}\text { PGA_RAN }^{2} \\
(\mathrm{~g})\end{array}$ & $\begin{array}{c}\Delta_{\text {PGA }} \\
\left(\mathrm{T}_{\mathrm{R}}=475\right) \\
(\%)\end{array}$ & $\begin{array}{c}\Delta_{\text {PGA }} \\
\left(\mathrm{T}_{\mathrm{R}}=975\right) \\
(\%)\end{array}$ & $\begin{array}{c}\Delta_{\text {PGA }} \\
\left(\mathrm{T}_{\mathrm{R}}=2475\right) \\
(\%)\end{array}$ \\
\hline \multirow{4}{*}{ AMT } & $\mathrm{WE}$ & 0.2988 & 0.3588 & 0.450 & 0.8508 & -184.7 & -137.1 & -88.9 \\
& $\mathrm{NS}$ & 0.2988 & 0.3588 & 0.450 & 0.3684 & -23.3 & -2.07 & 18.2 \\
& $\mathrm{ROT}$ & 0.2988 & 0.3588 & 0.450 & 0.8508 & -184.7 & -137.1 & -88.9 \\
\hline \multirow{3}{*}{$\mathrm{CNE}$} & $\mathrm{WE}$ & 0.3334 & 0.3936 & 0.461 & 0.5270 & -58.0 & -33.9 & -14.3 \\
& $\mathrm{NS}$ & 0.3334 & 0.3936 & 0.461 & 0.3731 & -11.9 & 5.2 & 19.1 \\
& $\mathrm{ROT}$ & 0.3334 & 0.3936 & 0.461 & 0.5270 & -58.0 & -33.9 & -14.3 \\
\hline
\end{tabular}




\begin{tabular}{|c|c|c|c|c|c|c|c|c|}
\hline \multirow{2}{*}{ NRC } & WE & 0.2953 & 0.3551 & 0.447 & 0.4764 & -61.4 & -34.2 & -6.7 \\
& NS & 0.2953 & 0.3551 & 0.447 & 0.3651 & -23.6 & -2.8 & 18.3 \\
& ROT & 0.2953 & 0.3551 & 0.447 & 0.5137 & -74.0 & -44.6 & -15.0 \\
\hline
\end{tabular}

Table 4: Peak Ground Acceleration (PGA) values of the recording stations (AMT, CNE, NRC) and NTC08 Italian Code values for return periods equal to 475,975 and 2475 years and variations $\triangle \mathrm{PGA}$.

Code values are always lower than recorded data for $T_{R}=475, T_{R}=975$ and $T_{R}=2475$ years. The maximum difference between observed and code values are $-184.7 \%$ (WE and ROT direction), $-137.1 \%$ (WE and ROT direction) and $-88.9 \%$ (WE and ROT direction) at the AMT station, $-58 \%$ (WE and ROT direction), $-33.9 \%$ (WE and ROT direction) and $19.1 \%$ (NS direction) at the CNE station, -74\% (ROT direction ), $-44.6 \%$ (ROT direction ) and $18.3 \%$ (NS direction) at the NRC station, for the different return periods as showed in Table 4.

\subsection{Comparison in terms of Housner Intensity}

As described in the previous section, recorded and the Italian seismic code values have also been compared in terms of $\mathrm{I}_{\mathrm{H}}$. The differences between code (NTC08) and recorded (RAN) values have been reported in Table 5 for $T_{R}$ equal to 475, 975 and 2475 years, computed according to Eq. (3).

\begin{tabular}{|c|c|c|c|c|c|c|c|c|}
\hline $\begin{array}{c}\text { Station } \\
\text { Code }\end{array}$ & Direction & $\begin{array}{c}\mathrm{I}_{\mathrm{H} \_ \text {NTC08 }} \\
\left(\mathrm{T}_{\mathrm{R}}=475\right) \\
(\mathrm{m})\end{array}$ & $\begin{array}{c}\mathrm{I}_{\mathrm{H} \_\mathrm{NTC} 08} \\
\left(\mathrm{~T}_{\mathrm{R}}=975\right) \\
(\mathrm{m})\end{array}$ & $\begin{array}{c}\mathrm{I}_{\mathrm{H} \_\mathrm{NTC08}} \\
\left(\mathrm{T}_{\mathrm{R}}=2475\right) \\
(\mathrm{m})\end{array}$ & $\begin{array}{c}\mathrm{I}_{\mathrm{H} \_\mathrm{RAN}} \\
(\mathrm{m})\end{array}$ & $\begin{array}{c}\Delta \mathrm{I}_{\mathrm{H}} \\
\left(\mathrm{T}_{\mathrm{R}}=475\right) \\
(\%)\end{array}$ & $\begin{array}{c}\Delta \mathrm{I}_{\mathrm{H}} \\
\left(\mathrm{T}_{\mathrm{R}}=975\right) \\
(\%)\end{array}$ & $\begin{array}{c}\Delta \mathrm{I}_{\mathrm{H}} \\
\left(\mathrm{T}_{\mathrm{R}}=2475\right) \\
(\%)\end{array}$ \\
\hline \multirow{4}{*}{ AMT } & $\mathrm{WE}$ & 0.902 & 1.204 & 1.531 & 0.654 & 27.5 & 45.7 & 57.3 \\
& $\mathrm{NS}$ & 0.902 & 1.204 & 1.531 & 0.929 & -3.0 & 22.8 & 39.3 \\
& $\mathrm{ROT}$ & 0.902 & 1.204 & 1.531 & 0.654 & 27.5 & 45.7 & 57.3 \\
\hline \multirow{3}{*}{$\mathrm{CNE}$} & $\mathrm{WE}$ & 1.125 & 1.381 & 1.603 & 0.692 & 38.4 & 49.9 & 56.8 \\
& $\mathrm{NS}$ & 1.125 & 1.381 & 1.603 & 0.840 & 25.3 & 39.2 & 47.6 \\
& $\mathrm{ROT}$ & 1.125 & 1.381 & 1.603 & 0.692 & 38.4 & 49.9 & 56.8 \\
\hline \multirow{3}{*}{$\mathrm{NRC}$} & $\mathrm{WE}$ & 0.878 & 1.172 & 1.488 & 1.746 & -98.8 & -49.0 & -17.3 \\
& $\mathrm{NS}$ & 0.878 & 1.172 & 1.488 & 1.252 & -42.5 & -6.8 & 15.9 \\
& $\mathrm{ROT}$ & 0.878 & 1.172 & 1.488 & 1.651 & -87.9 & -40.9 & -10.9 \\
\hline
\end{tabular}

Table 5: Housner intensity (IH) values of the recording stations (AMT, CNE, NRC) and NTC08 Italian Code values for return periods equal to 475,975 and 2475 years and variations $\Delta \mathrm{IH}$.

$$
I_{H}, T_{R}=\left(100 \cdot \frac{I_{H, N T C 08}-I_{H, R A N}}{I_{H, N T C 08}}\right)_{T_{R}}
$$

Comparisons in terms of $\mathrm{I}_{\mathrm{H}}$ show that code values are generally higher than recorded values at the AMT station for the three different return periods. The values computed using code spectra are generally comparable with those from recorded data for $T_{R}=475$ years at the CNE station. The minimum variation $\Delta \mathrm{I}_{\mathrm{H}}$ between code and recorded data are exhibited for $\mathrm{T}_{\mathrm{R}}=2475$ years at the NRC station.

\subsection{Comparison in terms of elastic response spectra}

Analyses and comparisons in terms of peak values provide a clear reading of earthquake ground motion through parameters usually used in seismic design. Therefore, in this section, 
in order to give a description of the potential ground motion severity, elastic response spectra have been evaluated for the seismic time histories recorded at the three stations. As for PGA and $\mathrm{I}_{\mathrm{H}}$, the estimated elastic response spectra have been compared with the ones provided by NTC08 Italian Code considering the return periods of 475, 975 and 2475 years and the different soil type conditions of the accelerometric stations.

Computed and code response spectra are displayed in the figures 11, 12 and 13 in terms of pseudo-acceleration $(\mathrm{Sa})$, considering the horizontal components (NS and WE) of recorded signals.

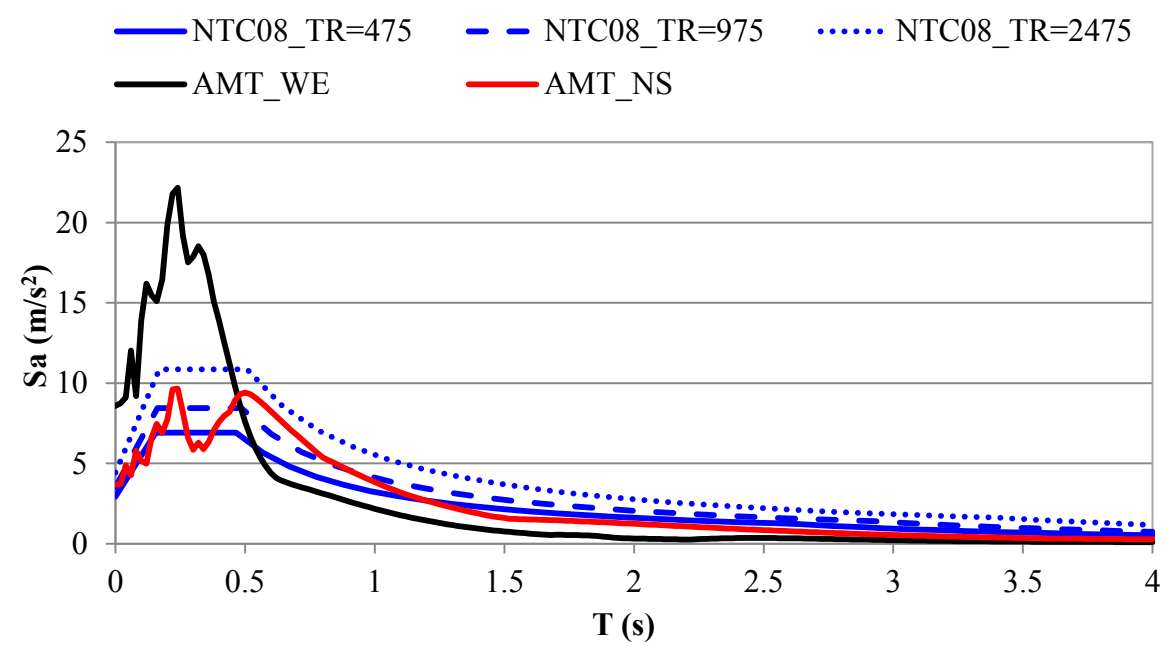

Figure 11: Comparison of the pseudoacceleration response spectra $\mathrm{S}(\mathrm{T}, \xi=5 \%)$ of the Amatrice recording station and of the NTC08 Italian Code for the return period of 475, 975 and 2475 years.

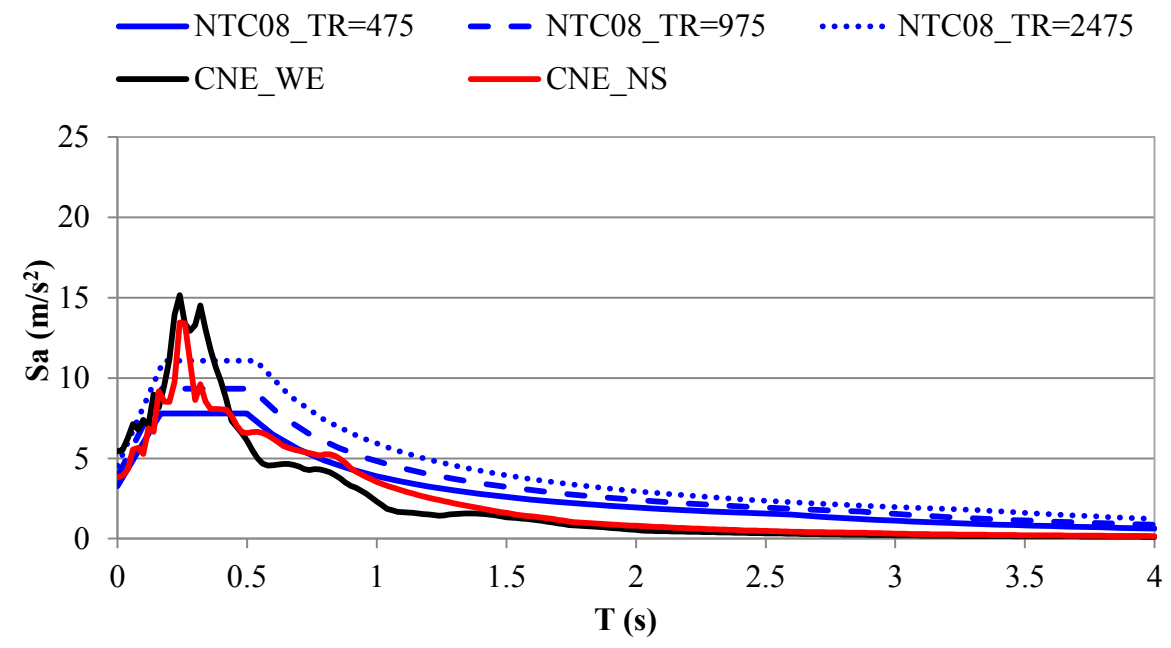

Figure 12: Comparison of the pseudoacceleration response spectra $\mathrm{S}(\mathrm{T}, \xi=5 \%)$ of the Castelsantangelo sul Nera recording station and of the NTC08 Italian Code for the return period of 475, 975 and 2475 years. 


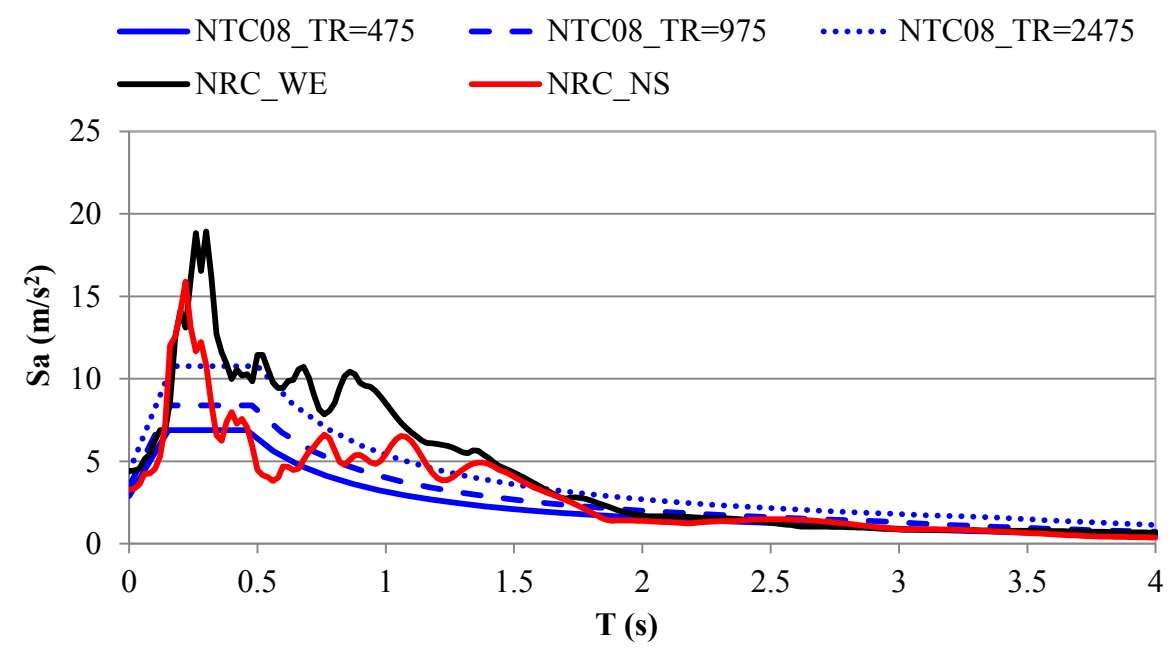

Figure 13: Comparison of the pseudoacceleration response spectra $S(T, \xi=5 \%)$ of the Norcia recording station and of the NTC08 Italian Code for the return period of 475,975 and 2475 years.

Comparison in terms of pseudo-acceleration response spectra $S a$ showed in figure 11 shows that the spectral values from NTC08 are by far lower than those from the recorded signals for WE direction, while, the recorded response spectrum is comparable with the code spectrum for $\mathrm{T}_{\mathrm{R}}=975$ years for NS direction.

Figure 12 shows that the recorded response spectra (NS and WE direction) are higher than the spectral values from NTC08 for the three different return periods considered in this work, particularly in the range of periods between 0.15 and $0.4 \mathrm{~s}$. Response spectra obtained from recorded data of the event of October $30^{\text {th }}$ (NRC station), as for the Castelsantangelo sul Nera recording station, are higher than the spectral values from NTC08 for the three different return periods $\left(T_{R}=475, T_{R}=975, T_{R}=2475\right.$ years) (Figure 13). Particularly in the WE direction, pseudo-acceleration $(\mathrm{Sa})$ are about twice the spectral values from NTC08 for $\mathrm{T}_{\mathrm{R}}=2475$ years, in the range of periods between 0.15 and $0.35 \mathrm{~s}$.

Figure 14 shows the probabilities in 50 years at towns of Amatrice, Castelsantangelo sul Nera and Norcia returned by NTC08 code for their respective soil class (the class of the recording stations reported in Table 1) as a function of PGA (Figure 14a) and $\mathrm{I}_{\mathrm{H}}$ (Figure 14b). The maximum value of PGA and $\mathrm{I}_{\mathrm{H}}$ for each recording stations has been depicted.

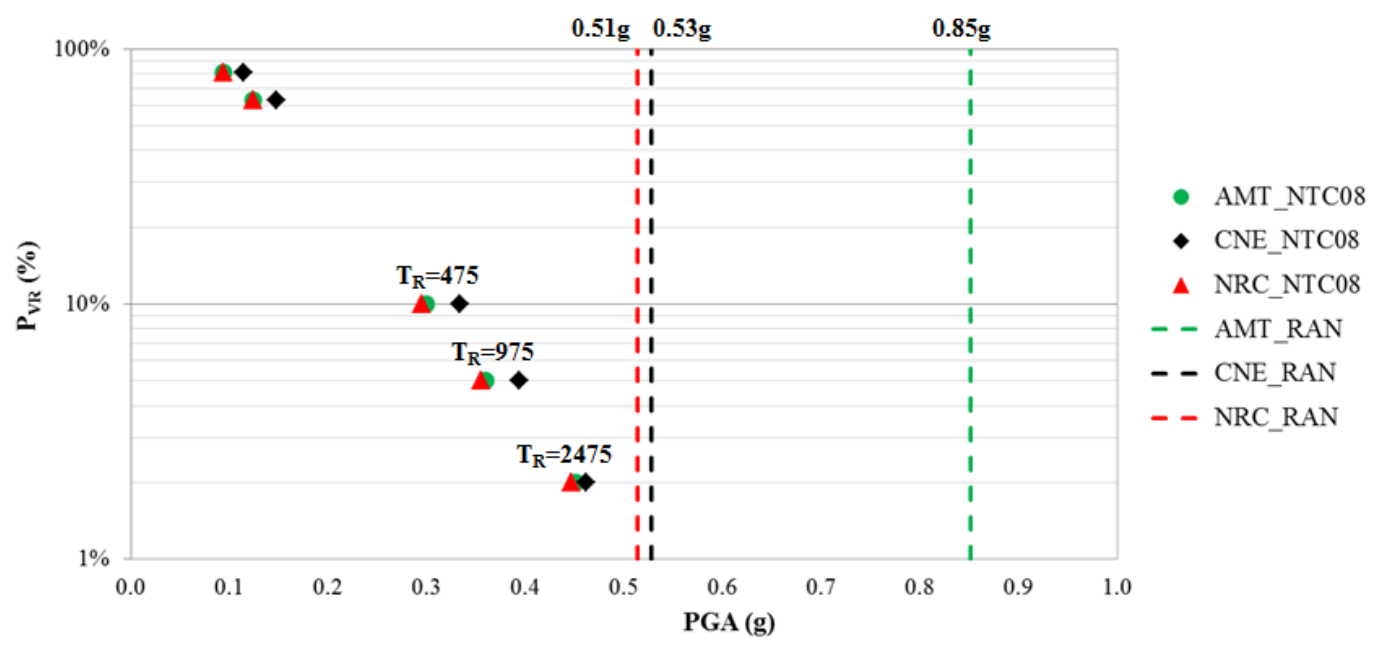


(b)

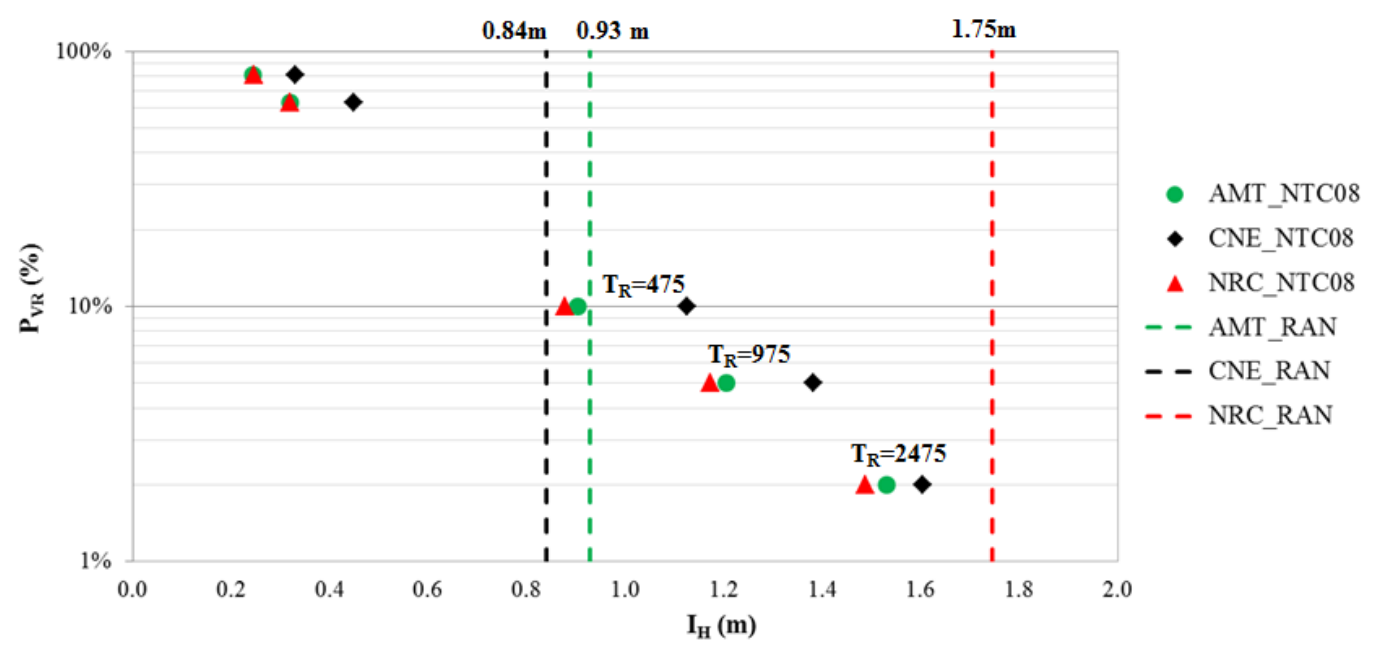

Figure 14: Exceedance probability in 50 years at three considered towns provided by the NTC2008 code in terms of PGA (a) and Housner Intensity (b).

The maximum PGA of the earthquakes recorded on October 26, 2016(CNE station) and October 30, 2016 (NRC station) would correspond to a return period of 2475 years, while the maximum PGA of the earthquake recorded on August 24, 2016 (AMT station) is about twice the value corresponding to $T_{R}=2475$ years. In terms of $I_{H}$, recorded data from AMT and CNE stations shows that maximum $\mathrm{I}_{\mathrm{H}}$ are close to the values corresponding to a return period of 475 years. Maximum value for NRC station would correspond to a return period larger than 2475 years.

\section{DISCUSSION AND FINAL REMARKS}

The earthquake occurred on October 30, 2016 at 06:40:17 UTC, (07:40:17, local time) is the Italian strongest event after the 1980 Irpinia earthquake $\left(M_{W} 6.9\right)$. The local magnitude evaluated by the INGV is equal to $6.1 \mathrm{M}_{\mathrm{L}}$ while the moment magnitude is equal to $6.5 \mathrm{M} \mathrm{W}$. In order to compare recorded and code provision values in terms of peak, spectral and integral parameters, several preliminary analyses have been performed on accelerometric timehistories acquired by three near fault station of the RAN network: Amatrice station (station code AMT), Norcia station (station code NRC) and Castelsantangelo sul Nera station (station code $\mathrm{CNE}$ ).

As expected, results retrieved from these preliminary analyses highlights several apparent difference between experimental data and conventional code provision. Taking into account the results retrieved in terms of PGA, experimental data showed peaks higher than those provided by the NTC 2008 code when a return period equal to 475 years is considered. On the contrary, considering a return period equal to 2475, recordings and NTC 2008 code provide comparable peaks values for the earthquakes recorded on October 26, 2016(CNE station) and October 30, 2016 (NRC station).The PGA of the earthquake recorded on August 24, 2016 (AMT station) is about twice the value corresponding to $T_{R}=2475$ years. Then, the ongoing seismic sequence appears compatible with the historical seismicity in terms of integral parameters, but not in terms of peak and spectral values. It seems appropriate to reconsider the necessity to revise the simplified design approach based on the conventional spectral values.

Last, but not least, a significant soil amplification has been documented in the historical centre of Amatrice town in the frequency range $2-5 \mathrm{~Hz}$. 
In order to complete this preliminary work more measurements and analyses on soil and buildings are necessary for better understand a possible role played by soil-structure interaction effects on the damage observed within the city located into the area interested by the ongoing seismic sequence in Central Italy.

\section{ACKNOWLEDGEMENTS}

This study was partially funded by the Italian Civil Protection Department within the project DPC-RELUIS 2016 - RS4 "Seismic observatory of structures and health monitoring", and by the "Centre of Integrated Geomorphology for the Mediterranean Area - CGIAM" within the Framework Agreement with the University of Basilicata for the "Study, Research and Experimentation in the Field of Analysis and Monitoring of Seismic Vulnerability of Strategic and Relevant Buildings for the purposes of Civil Protection and Development of Innovative Strategies of Seismic Reinforcement".

\section{REFERENCES}

[1] INGV, Summary report on the 30 October, 2016 Earthquake in central Italy MW 6.5, 2016.

[2] F.C. Ponzo, R. Ditommaso, A. Nigro, D. Spina, Valutazioni preliminari su possibili fenomeni di interazione terreno-struttura rilevate nelle aree colpite dal sisma del 24/08/2016. 35 edizione del Convegno GNGTS, Lecce, 22-24 novembre 2016.

[3] ITACA, $2008 \mathrm{http}: / /$ itaca.mi.ingv.it.

[4] CEN Eurocode 8. Design of structures for earthquake resistance - Part 1: General rules, seismic actions and rules for buildings. EN 1998-1, Brussels, 2004.

[5] W.B. Joyner, D.M. Boore, Peak horizontal acceleration and velocity from strong-motion records including records from the 1979 Imperial Valley, California, earthquake. Bull Seismol Soc Am 71:2011-2038, 1981.

[6] L. Decanini, F. Mollaioli, G. Oliveto, Structural and seismological implications of the 1997 seismic sequence in Umbria and Marche, Italy. Innovative approaches to earthquake engineering. In: Oliveto G (ed) WIT Press, Southampton, pp 229-323, 2002.

[7] A. Masi, M. Vona, M. Mucciarelli, Selection of natural and synthetic accelerograms for seismic vulnerability studies on RC frames. J Struct Eng. doi:10.1061/(ASCE)ST.1943$541 X .209,2010$.

[8] G.W. Housner, Intensity of ground motion during strong earthquakes. Second technical report. August 1952, California Institute of Technology, Pasedena, California, 1952.

[9] A. Masi, L. Chiauzzi, F. Braga, M. Mucciarelli, M. Vona, R. Ditommaso, Peak and integral seismic parameters of L'Aquila 2009 ground motions: observed versus code provision values. Bull Earthquake Eng. 9:139-156, 2011.

[10] GNDT Working Group, Proposta di riclassificazione sismica del territorio nazionale (in Italian). Ingegneria Sismica. XVI N.1, gennaio-aprile 1999.

[11] Nuove norme tecniche per le costruzioni. D.M. Infrastrutture 14 Gennaio 2008. 